\title{
Corn Silage (Zea mays L.) Response to Zinc Foliar Spray Concentration When Grown on Sandy Soil
}

\author{
Saad Drissi ${ }^{1}$, Abdelhadi Aït Houssa ${ }^{2}$, Ahmed Bamouh $^{1} \&$ Mohamed Benbella $^{2}$ \\ ${ }^{1}$ Plant Production, Protection and Biotechnology Department, Hassan II Agronomy and Veterinary Institute, \\ Rabat, Morocco \\ ${ }^{2}$ Department of Agronomy and Plant Breeding, National Agricultural School of Meknes, Meknes, Morocco \\ Correspondence: Saad Drissi, Plant Production, Protection and Biotechnology Department, Hassan II Agronomy \\ and Veterinary Institute, Rabat, Morocco. E-mail: drissi_agro@yahoo.com
}

Received: September 25, 2014 Accepted: November 20, $2014 \quad$ Online Published: January 15, 2015

doi:10.5539/jas.v7n2p68 URL: http://dx.doi.org/10.5539/jas.v7n2p68

\begin{abstract}
The objective of this study is to identify an adequate zinc ( $\mathrm{Zn}$ ) foliar spray concentration which corrects $\mathrm{Zn}$ deficiency without disrupting other plant mineral contents, enhances plant growth, and thereby corn silage yield when grown on sandy soil. A field experiment was conducted using five $\mathrm{Zn}$ foliar spray concentrations (w/v): $0.03 \%, 0.07 \%, 0.10 \%, 0.14 \%$ and $0.18 \%$. $\mathrm{Zn}$ sulfate $\left(\mathrm{ZnSO}_{4} .7 \mathrm{H}_{2} \mathrm{O}\right)$ was used as a source of $\mathrm{Zn}$. $\mathrm{Zn}$ foliar application was realized at two growth stages (6-7 and 9-10 leaf stages). A treatment without Zn foliar spray was maintained as control. The results showed a quadratic response of corn silage towards $\mathrm{Zn}$ foliar spray concentrations, in which $0.09 \%$ was the optimum value for overcoming $\mathrm{Zn}$ deficiency. Such level increased shoot $\mathrm{Zn}$ concentration at harvest from $15 \mathrm{mg} \mathrm{kg}^{-1}$ to $21.8 \mathrm{mg} \mathrm{kg}^{-1}$, didn't decrease plant mineral content below critical levels, enhanced plant growth and raised silage yield by $49.4 \%$ compared to control. On the other hand, $\mathrm{Zn}$ foliar spray concentration up to $0.10 \%$ induced visible leaf damage, growth inhibition and a decrease of $26 \%$ in silage yield compared to $\mathrm{Zn}$ foliar applications at $0.09 \%$.
\end{abstract}

Keywords: corn silage, $\mathrm{Zn}$ deficiency, Zn foliar spray, growth, mineral content, yield

\section{Introduction}

Most plant micro-nutrition research has reported the severe effects of $\mathrm{Zn}$ deficiency on crop productivity especially for cereals (Cakmak, 2008). Corn (Zea mays L.) is one of the very sensitive cereal species to $\mathrm{Zn}$ deficiency stress (Lindsay \& Norvel, 1977; Gupta, Kening, \& Siyuan, 2008). Many authors have reported importance of $\mathrm{Zn}$ in completing some vital physiological functions such as energy production and protein synthesis (Hansch \& Mendel, 2009; Gupta et al., 2008; Mousavi, Galavi, \& Rezaei, 2013; Qiao et al., 2014).

Under Zn deficiency, corn has low Zn concentration, usually below the critical level of $22 \mathrm{mg} \mathrm{kg}^{-1}\left(\mathrm{Singh}_{\text {, }}\right.$ Natesan, Singh, \& Usha, 2005), and shows white linear bands between the midrib and the margin of leaves (Singh et al., 2005), as well as an obvious shortening of plant height and leaf area (De Vasconcelos, Clístenes, \& Fernando, 2011). All this result in significant decline in silage and grain yields (Van Biljon, Wright, Fouche, \& Botha, 2010; Potarzycki \& Grzebisz, 2009). In order to prevent Zn deficiency stress, both soil Zn supply and Zn foliar spray have been advisable. In the context of many dairy farmlands from Loukkos perimeter (North West of Morocco), corn silage grown on a sandy soil, naturally poor in $\mathrm{Zn}$, showed $\mathrm{Zn}$ deficiency symptoms that resulted in a silage yield decline compared to adequate fertilized plots receiving either $\mathrm{Zn}$ sulfate or animal manures. $\mathrm{Zn}$ foliar spray is still not a common fertilization method in this region, except some commercial mixtures of macro and micronutrients that provided a partial recovery from $\mathrm{Zn}$ deficiency stress. Many authors have reported the importance of $\mathrm{Zn}$ foliar applications at adequate levels to improve yields of many grown crops such as corn (Potarzycki \& Grzebisz, 2009), wheat grain (Haslett, Reid, \& Rengel, 2001), tomato fruit (Kaya \& Higgs, 2002) and safflower (Rajabi et al., 2013). The foliage uptake depends on many factors such as plant species, timing of application, and concentration (Wojcik, 2004). Knoche, Petracek, Bukovac, and Shafer (1994) reported linear positive relationship between nutrient foliar spray concentration and the rate of its uptake by tomato's leaves. Potarzycki and Grzebisz (2009) found positive quadratic relationship between Zn foliar spray concentration and corn grain yield. They have denoted optimal yielding at concentration ranging between $0.25 \%$ and $0.37 \%$ of $\mathrm{Zn}$ applied at 5 leaf stage. Also, Takkar and Wallker (1993) reported that Zn foliar spray concentration at 0.5-1\% of 
$\mathrm{ZnSO}_{4} \cdot 7 \mathrm{H}_{2} \mathrm{O}$ resulted in optimal biomass yields for many crops.

On the other hand, Zn foliar applications at high concentration induced leaf injury (Qiao et al., 2014), inhibited plant growth and declined yield (Kaya \& Higgs, 2002). Moreover, it may disrupt the uptake of other macro and micronutrients. In this respect, Kaya and Higgs (2002) found that the increase of Zn foliar spray concentration on tomato increased leaves $\mathrm{Zn}$ concentration, but reduced potassium $(\mathrm{K})$, magnesium $(\mathrm{Mg})$ and iron $(\mathrm{Fe})$ contents.

Despite numerous advantages of foliar spray such as being environmentally friendly, inexpensive and fast in correcting deficiency, we found little literature about managing $\mathrm{Zn}$ foliar spray for adequate mineral content and corn silage growth. Therefore, the present study was undertaken with the objective of identifying an adequate concentration of $\mathrm{Zn}$ to spray on corn silage grown on a sandy soil in order to correct $\mathrm{Zn}$ deficiency without disrupting mineral composition and plant growth.

\section{Method}

\subsection{Site Description}

A field experiment was conducted on an agricultural farm (Bassita II farm) located in Loukkos perimeter $\left(34^{\circ} 96^{\prime} \mathrm{N}\right.$ lat., $6^{\circ} 21^{\prime} \mathrm{W}$ long., $60 \mathrm{~m}$ above the sea level, North West of Morocco) where the climate is maritime. We recorded, during the growing season (August 09 to November 20, 2012), $16.6{ }^{\circ} \mathrm{C}$ and $24.2{ }^{\circ} \mathrm{C}$ as average of maximum and minimum temperatures, respectively. A rainfall amount of $283 \mathrm{~mm}$ was recorded especially between September and November. A comparison between the studied growing season weather and the climatic data of the last 40 years (1971-2010)* of the experimental site is reported in Table1.

Table 1. Temperature, evapotranspiration and rainfall during the growing season (August to November) for 2012 and long-term means (1971-2010) of the experimental site

\begin{tabular}{|c|c|c|c|c|c|c|c|c|}
\hline & \multicolumn{2}{|c|}{ Min temperature $\left({ }^{\circ} \mathrm{C}\right)$} & \multicolumn{2}{|c|}{ Max temperature $\left({ }^{\circ} \mathrm{C}\right)$} & \multicolumn{2}{|c|}{$\begin{array}{l}\text { Evapotranspiration } \\
\qquad\left(\mathrm{mm} \mathrm{day}^{-1}\right)\end{array}$} & \multicolumn{2}{|c|}{ Rainfall (mm) } \\
\hline & 2012 & $1971-2010$ & 2012 & $1971-2010$ & 2012 & $1971-2010$ & 2012 & $1971-2010$ \\
\hline August & 19.3 & 18.9 & 25.7 & 27.5 & 4.0 & 4.0 & 4 & 1.8 \\
\hline September & 17.5 & 17.6 & 24.8 & 26.4 & 3.6 & 3.8 & 47 & 17.8 \\
\hline October & 16.3 & 14.9 & 25.6 & 23.7 & 3.5 & 3.2 & 88 & 67.2 \\
\hline November & 11.4 & 11.3 & 20.4 & 20.1 & 2.5 & 2.5 & 171 & 114.1 \\
\hline
\end{tabular}

*Source: Taken from National Directorate of Meteorology (DMN), Morocco.

\subsection{Experimental Soil}

For basic soil characteristics analysis, we collected a soil sample $0-20 \mathrm{~cm}$. The soil was sandy $(88.8 \%$ of sand, $7.5 \%$ of clay and $5.3 \%$ of silt), no calcareous, with a very low amount of DTPA extractable $\mathrm{Zn}\left(0.13 \mathrm{mg} \mathrm{kg}^{-1}\right)$, which was below the critical level of $0.8 \mathrm{mg} \mathrm{kg}^{-1}$ required for corn (Landsay \& Norvel, 1977). The other soil chemical characteristics are listed in Table 2. 
Table 2. Soil characteristics

\begin{tabular}{|c|c|}
\hline \multicolumn{2}{|l|}{ Soil property } \\
\hline $\mathrm{pH} \mathrm{H}_{2} \mathrm{O}(1 / 5)$ & 6.1 \\
\hline Cation exchange capacity (meq $\left.100 \mathrm{~g}^{-1}\right)$ (Cobaltihexamine Chloride method) & 4.4 \\
\hline Organic matter (\%) (Walkley \& Black method) & 0.4 \\
\hline Extractable $\mathrm{P}_{2} \mathrm{O}_{5}\left(\mathrm{mg} \mathrm{kg}^{-1}\right)$ (Olsen method) & 49 \\
\hline Extractable $\quad \mathrm{K}_{2} \mathrm{O}\left(\mathrm{mg} \mathrm{kg}^{-1}\right) \mathrm{a}$ & 81 \\
\hline Extractable $\mathrm{MgO}\left(\mathrm{mg} \mathrm{kg}^{-1}\right) \mathrm{a}$ & 101 \\
\hline Extractable $\mathrm{CaO}\left(\mathrm{mg} \mathrm{Kg}^{-1}\right) \mathrm{b}$ & 868 \\
\hline Extractable $\mathrm{Zn}\left(\mathrm{mg} \mathrm{kg}^{-1}\right) \mathrm{c}$ & 0.13 \\
\hline Extractable $\mathrm{Cu}\left(\mathrm{mg} \mathrm{kg}^{-1}\right) \mathrm{c}$ & 0.06 \\
\hline Extractable Mn $\left(\mathrm{mg} \mathrm{kg}^{-1}\right) \mathrm{c}$ & 17.4 \\
\hline Extractable Fe $\left(\mathrm{mg} \mathrm{kg}^{-1}\right) \mathrm{c}$ & 17.45 \\
\hline
\end{tabular}

Extractants: $\mathrm{a}=$ Ammonium Acetate.; $\mathrm{b}=$ Sodium Acetate; $\mathrm{c}=$ Diethylene Triamine Penta-Acetic acid (DTPA).

\subsection{Crop Management and Experimental Design}

The land was prepared for planting by cultivator tillage. Corn hybrid Panama was planted on 09 August 2012. The sowing was done on twin lines with a spacing of $45 \mathrm{~cm}, 90 \mathrm{~cm}$ between twin lines spacing and the inter-row seeding distance was $12 \mathrm{~cm}$ to approximate 120,000 plants ha $^{-1}$.

A completely randomized block design with five replications was used. Plots included 3 twin lines of plants, $4 \mathrm{~m}$ width and $8 \mathrm{~m}$ length. There were $4 \mathrm{~m}$ between adjacent plots in the same block and $1.4 \mathrm{~m}$ between adjacent blocks.

Five $\mathrm{Zn}$ foliar spray concentrations (w/v) were tested: $0.03 \%, 0.07 \%, 0.10 \%, 0.14 \%$ and $0.18 \%$. $\mathrm{Zn}$ sulfate $\left(\mathrm{ZnSO}_{4} \cdot 7 \mathrm{H}_{2} \mathrm{O}, 22.5 \%\right.$ of $\left.\mathrm{Zn}\right)$ was used as source of $\mathrm{Zn}$. The foliar spray, about $6251 \mathrm{ha}^{-1}$, was done using a hand-held sprayer in an early and windless morning. The spray was done twice during the growth season at: i) 5-6 leaf stage and ii) 9-10 leaf stage. A treatment without $\mathrm{Zn}$ foliar spray was maintained as control. In order to ensure an adequate nutrition with other nutrient elements, all treatments received adequate amounts of macro and micro elements during the growing season: $480 \mathrm{Kg} \mathrm{ha}^{-1}$ of $\mathrm{N}$ as ammonium nitrate and diammonium phosphate (DAP), $345 \mathrm{Kg} \mathrm{ha}^{-1}$ of $\mathrm{P}_{2} \mathrm{O}_{5}$ as DAP, $331 \mathrm{Kg} \mathrm{ha}^{-1}$ of $\mathrm{K}_{2} \mathrm{O}$ as potassium sulfate, $6.25 \mathrm{Kg} \mathrm{ha}^{-1}$ of Cu as copper sulfate, $4.61 \mathrm{Kg} \mathrm{ha}^{-1}$ of $\mathrm{B}$ as boron sulfate and $3.35 \mathrm{Kg} \mathrm{ha}^{-1}$ of Mn as manganese sulfate.

Each line of plants was equipped with a drip line irrigation system using $1.21 \mathrm{~h}^{-1}$ emitters and $0.4 \mathrm{~m}$ as emitters spacing. Watering was done whenever required during the growing season. Weeds were controlled using a mixture of pre-emergence herbicides (Pendimethaline, Mesotrione, Terbuthylazine and S-metolachlor) and fungal disease (Helmintosporium) was controlled with Epoxiconazole.

\subsection{Measurements}

Taking into account that $\mathrm{Zn}$ deficiency symptoms appeared on corn as white linear areas between the midrib and margin of leaves (Singh et al., 2005; Alloway, 2008), visual Zn deficiency symptoms evolution was determined each 10 days, on 10 randomly chosen plants for each treatment's replication. The symptoms were summarized using a descriptive scale of 1 to 5: $1=$ plants had no visual $\mathrm{Zn}$ deficiency symptoms, $2=$ pale green linear stripes began to appear between the midrib and the margin of new leaves, $3=$ white linear stripes appeared between the midrib and the margin of all leaves 4 = white bands appeared between the midrib and the margin of old leaves, 5 $=$ all leaves were small showing linear white bands between their midrib and margin.

The stem height and the stem diameter were measured, on 10 randomly chosen plants per each treatment's replication, at 3 different growing stages: 6-7 leaf stage, 9-10 leaf stage and harvest.

The total leaf area per plant at harvest was measured in 3 randomly chosen plants per each treatment's replication using the formula (1) developed by Montgomery (1911) and cited in Mokhtarpour et al. (2010) for corn: 


$$
\text { Total leaf area per plant }=\sum_{i=1}^{j=n}(L \times W \times 0.75)
$$

Where L, W, and $\mathrm{n}$ are leaf length, leaf greatest width, and last leaf of corn, respectively.

The harvest was done manually on November 20, 2012, approximately at shoot moisture content of $67 \%$. 10 randomly chosen plants per each treatment's replication were cut close to the soil surface, and the fresh weights of the harvest were measured. 3 randomly chosen ears per each treatment's replication were taken in order to determine different kernels yield compounds: i) total number of ovules per ear using equation (2) ii) pollination rate using equation (3), and iii) thousand-kernel dry weight.

$$
\begin{aligned}
& \text { Total number of ovules per ear }=\text { Number of kernels }+ \text { Number of sterilized ovules } \\
& \text { Pollination rate }(\%)=\text { Number of kernels per ear/Total number of ovules per ear } \times 100
\end{aligned}
$$

In order to evaluate macro and micro nutrients shoot contents at harvest, 3 plants from each of the following treatments (Control, $0.03 \%, 0.10 \%$ and $0.18 \%$ ) were dried at $70{ }^{\circ} \mathrm{C}$ in an oven until constant weight, chopped and mixed. Thereafter, 3 subsamples of $0.6 \mathrm{~g}$ per these treatments were digested with a mixture of salicylic and sulfuric acids in order to determine plant $\mathrm{N}, \mathrm{P}, \mathrm{K}, \mathrm{Ca}$ and $\mathrm{Mg}$ contents. Besides, 3 other subsamples of $2 \mathrm{~g}$ were digested with a mixture of nitric, perchloric, and sulfuric acids to determine plant $\mathrm{Zn}, \mathrm{Mn}, \mathrm{Fe}$ and $\mathrm{Cu}$ contents.

Concerning $\mathrm{K}, \mathrm{Ca}, \mathrm{Mg}, \mathrm{Zn}, \mathrm{Fe}$ and $\mathrm{Mn}$, they were analyzed using an atomic absorption spectrophotometer (Varian AA 240 Fast Sequential; air acetylene flame). However, N and P were auto-analyzed using a continuous flow analyzer (Skalar $\mathrm{San}^{++}$).

\subsection{Statistical Analysis}

All data were subjected to analysis of variance at 5\% significance level. Taking into account that $\mathrm{Zn}$ concentration treatment is a quantitative variable, an appropriate regression analysis, which was selected on the basis of higher $\mathrm{r}^{2}$, was used to evaluate the response of each measured parameter. The optimum $\mathrm{Zn}$ foliar spray for each parameter was determined by equating the first derivative of the regression equation to zero. These statistical analyses were performed using the program SPSS (Version 17.0).

\section{Results}

\subsection{Visual Zn Deficiency Symptoms}

Zn deficiency symptoms appeared at an earlier stage ( 5 leaf stage) as white linear stripes between the midrib and the margin of leaves for all treatments (score 3). Zn foliar applications up to $0.03 \%$ induced a clear disappearance of these symptoms $($ score $\approx 1)$. But, some green pale lines persisted on plants during all growing season even with high $\mathrm{Zn}$ foliar spray concentration $(0.14 \%$ and $0.18 \%)$. Control plants also showed a slight recovery from $\mathrm{Zn}$ deficiency at 8-9 leaf stage (score 2). On the other hand, due to high $\mathrm{Zn}$ level concentration (up to $0.10 \%$ ), an obvious leaf injury with brown leaf areas was observed after one day of each application. This damage concerned only the touched leaves, thereafter, new safety leaves appeared.

\subsection{Plant Growth}

Just after the first $\mathrm{Zn}$ foliar application (6-7 leaf stage), a clear increase on stem height was marked. At 9-10 leaf stage, all $\mathrm{Zn}$ foliar treatments induced a significant increase of $14.6 \%$ compared to control. While at harvest, a clear positive quadratic response was recorded. $\mathrm{Zn}$ foliar application at $0.10 \%$ induced the most significant stem height increase of $11.8 \%$ compared to control. Moreover, the total leaf area per plant at harvest was significantly raised. Compared to control, all $\mathrm{Zn}$ foliar treatments induced a significant rise of $23.40 \%$. Concerning stem diameter, it was significantly increased at 9-10 leaf stage. But at harvest, no significant difference between treatments was recorded. Nonetheless, an obvious growth inhibition was marked with high $\mathrm{Zn}$ foliar spray concentrations up to $0.10 \%$ (Table 3 ). 
Table 3. Effect of $\mathrm{Zn}$ foliar spray concentration (\%) on stem height, stem diameter and total leaf area of corn silage

\begin{tabular}{|c|c|c|c|c|c|c|c|}
\hline \multirow{2}{*}{$\begin{array}{l}\mathrm{Zn} \text { foliar spray } \\
\text { concentrations }\end{array}$} & \multicolumn{3}{|c|}{ Stem height $(\mathrm{cm})$} & \multicolumn{3}{|c|}{ Stem diameter $(\mathrm{cm})$} & \multirow{2}{*}{$\begin{array}{c}\text { Total leaf area } \\
\text { at harvest } \\
\left(\mathrm{dm}^{2} \text { plant }^{-1}\right)\end{array}$} \\
\hline & $\begin{array}{l}\text { 6-7 leaf } \\
\text { stage }\end{array}$ & $\begin{array}{l}\text { 9-10 leaf } \\
\text { stage }\end{array}$ & Harvest & $\begin{array}{l}\text { 6-7 leaf } \\
\text { stage }\end{array}$ & $\begin{array}{l}\text { 9-10 leaf } \\
\text { stage }\end{array}$ & Harvest & \\
\hline Control & $16.2 \pm 3.0$ & $39.8 \pm 12.5$ & $199.7 \pm 21.0$ & $1.2 \pm 0.2$ & $1.4 \pm 0.2$ & $1.4 \pm 0.2$ & $30.20 \pm 8.76$ \\
\hline 0.03 & $17.7 \pm 3.9$ & $46.5 \pm 10.8$ & $215.2 \pm 17.8$ & $1.3 \pm 0.2$ & $1.5 \pm 0.2$ & $1.5 \pm 0.1$ & $36.02 \pm 4.77$ \\
\hline 0.07 & $16.8 \pm 2.7$ & $45.9 \pm 9.9$ & $214.9 \pm 13.2$ & $1.2 \pm 0.2$ & $1.5 \pm 0.1$ & $1.4 \pm 0.2$ & $36.47 \pm 6.42$ \\
\hline 0.10 & $16.2 \pm 2.8$ & $45.5 \pm 8.1$ & $223.3 \pm 10.6$ & $1.2 \pm 0.2$ & $1.5 \pm 0.1$ & $1.5 \pm 0.2$ & $38.67 \pm 4.69$ \\
\hline 0.14 & $16.7 \pm 2.4$ & $44.4 \pm 7.9$ & $214.4 \pm 12.9$ & $1.3 \pm 0.2$ & $1.5 \pm 0.1$ & $1.4 \pm 0.2$ & $37.33 \pm 7.11$ \\
\hline 0.18 & $17.2 \pm 2.9$ & $45.7 \pm 10.4$ & $210.4 \pm 12.2$ & $1.3 \pm 0.2$ & $1.5 \pm 0.2$ & $1.4 \pm 0.2$ & $37.92 \pm 7.94$ \\
\hline F test & $*$ & $*$ & $*$ & n. s. & $*$ & n. s. & $*$ \\
\hline \multicolumn{8}{|l|}{ Regression } \\
\hline $\mathrm{r}^{2}$ & 0.03 & 0.50 & 0.81 & 0.06 & 0.65 & 0.42 & 0.86 \\
\hline $\mathrm{b}_{0}$ & 16.79 & 41.60 & 201.76 & 1.30 & 1.47 & 1.44 & 31.20 \\
\hline $\mathrm{b}_{1}$ & -2.63 & 82.71 & 362.42 & -0.44 & 2.03 & 1.12 & 115.87 \\
\hline $\mathrm{b}_{2}$ & 20.86 & -366.00 & -1787.11 & 2.53 & -8.86 & -7.33 & -455.74 \\
\hline
\end{tabular}

Data are the means \pm standard deviation.

* Significant at 5\% probability level; n.s.-Not significant at 5\% probability level.

\subsection{Silage Yield and Shoot Dry Matter Partitioning}

Silage yield was significantly influenced with $\mathrm{Zn}$ foliar spray. It had a positive quadratic response and the highest yield was recorded with $\mathrm{Zn}$ spray at $0.09 \%$. It induced an increase of $49.4 \%$ compared to control. However, a clear decline of about $26 \%$ in optimal yield was noted with $\mathrm{Zn}$ spray concentration up to $0.10 \%$ (Figure 1).

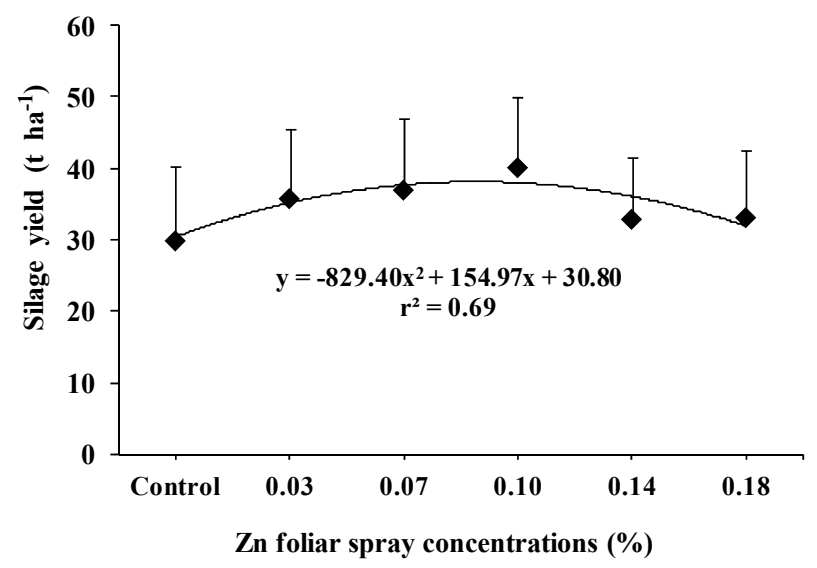

Figure 1. Effect of Zn foliar spray concentration on silage yield. Vertical bars denote standard deviation

The shoot dry matter partitioning analysis showed that stem, leaves and ear dry weights were all significantly enhanced by $\mathrm{Zn}$ foliar applications and had the same trend of the regression equation describing silage yield (Figure 2a). Within ear, we found that especially kernels dry weight was significantly influenced (Figure $2 b$ ). 

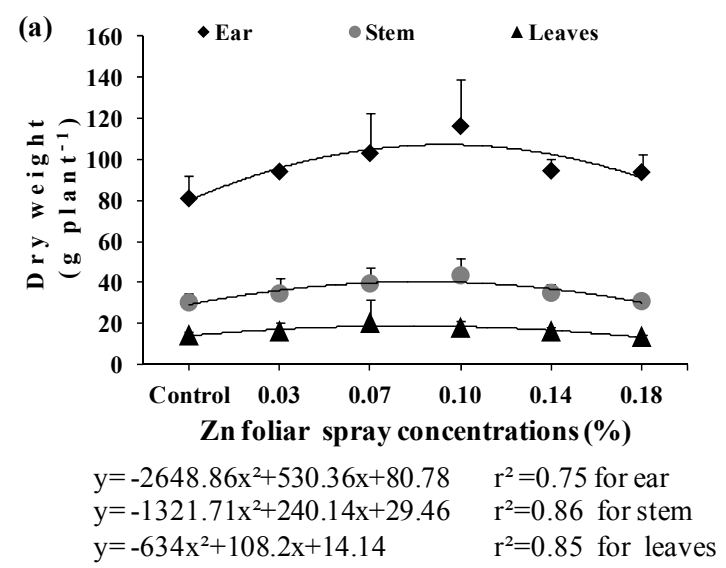

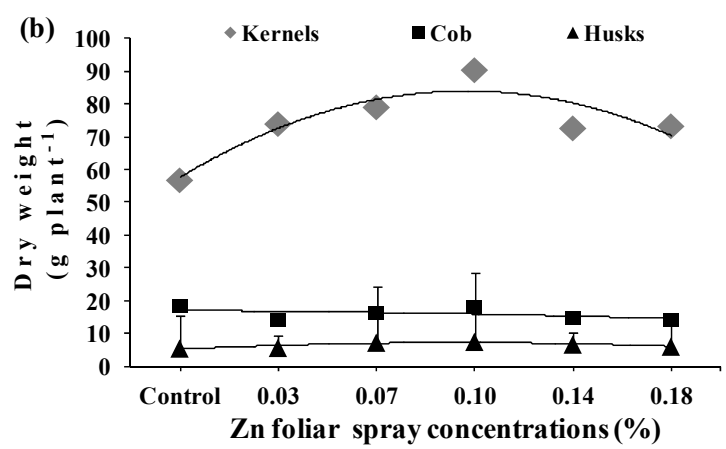

$$
\begin{array}{ll}
y=-2374.22 x^{2}+490.52 x+58.67 & r^{2}=0.77 \text { for kernels } \\
y=-196.4 x^{2}+39.69 x+5.25 & r^{2}=0.83 \text { for husks } \\
y=-78.24 x^{2}+0.14 x+16.86 & r^{2}=0.26 \text { for cob }
\end{array}
$$

Figure 2. Effect of $\mathrm{Zn}$ foliar spray concentration on shoot dry matter partitioning into ear, stem, leaves (a), kernels, cob and husks (b) of corn silage at harvest. Vertical bars denote standard deviation

The analysis of kernels yield components showed no significant effect of $\mathrm{Zn}$ foliar spray on the total number of ovules per ear (Figure 3a). But, two main components were significantly influenced: the pollination rate and the thousand-kernel dry weight (Figures $3 \mathrm{~b}$ and $3 \mathrm{c}$ ). Both had quadratic responses and the highest response was approximately at $0.10 \%$ of $\mathrm{Zn}$. Compared to control, this $\mathrm{Zn}$ rate induced significant increases of $15.4 \%$ and $19.1 \%$ on pollination rate and on thousand-kernel dry weight, respectively.
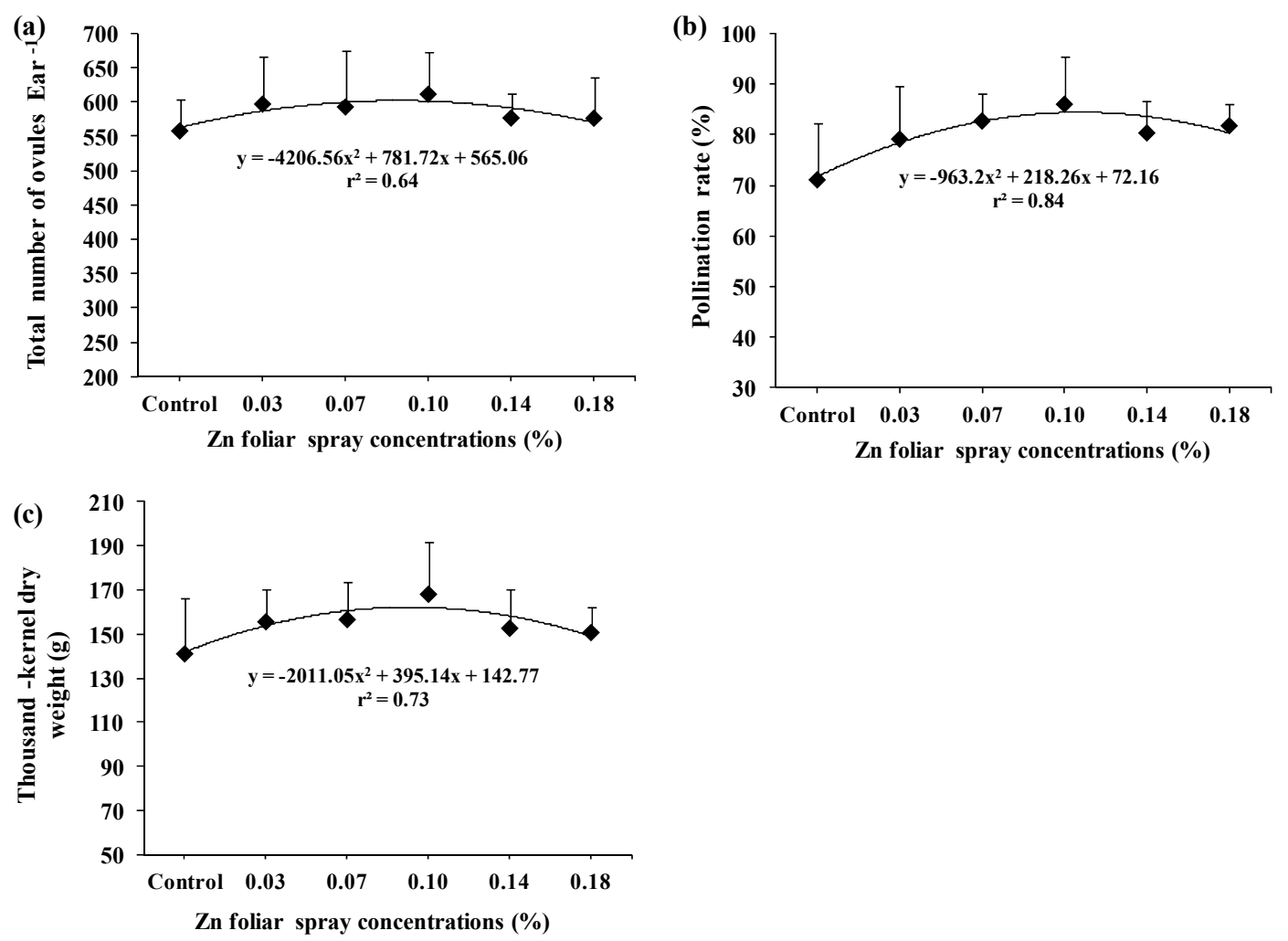

Figure 3. Effect of Zn foliar spray concentration on total number of ovules per ear (a), pollination rate (b) and thousand-kernel dry weight (c) of corn silage at harvest. Vertical bars denote standard deviation 


\subsection{Mineral Shoot Content}

\subsubsection{Micro Elements Shoot Content}

The chemical analysis of shoot dry matter at harvest showed that $\mathrm{Zn}$ foliar spray influenced some micro nutrients plant concentrations (Figures $4 \mathrm{a}, 4 \mathrm{~b}, 4 \mathrm{c}$ and $4 \mathrm{~d}$ ). The increase of $\mathrm{Zn}$ foliar spray concentration resulted in significant linear increase in shoot $\mathrm{Zn}$ content. $\mathrm{Zn}$ spray concentration at $0.09 \%$ which induced optimal yielding led to a shoot $\mathrm{Zn}$ content of $21.8 \mathrm{mg} \mathrm{kg}^{-1}$. However, plant concentration in $\mathrm{Mn}, \mathrm{Fe}$ and $\mathrm{Cu}$ showed linear significant decrease with increasing $\mathrm{Zn}$ foliar spray concentration. $\mathrm{Zn}$ foliar applications at $0.09 \%$ induced mineral contents of 93, 35.8, $6.7 \mathrm{mg} \mathrm{kg}^{-1}$ for $\mathrm{Fe}, \mathrm{Mn}$ and $\mathrm{Cu}$, respectively.

\subsubsection{Macro Elements Shoot Content}

Furthermore, shoot concentration in $\mathrm{K}$ and $\mathrm{Mg}$ had negative linear relationship with $\mathrm{Zn}$ concentration spray. At $\mathrm{Zn}$ foliar application of $0.09 \%$, we recorded $0.8 \%$ as shoot $\mathrm{k}$ content and $0.12 \%$ as $\mathrm{Mg}$ content (Figures $5 \mathrm{a}$ and $5 b)$.

In contrast, shoot $\mathrm{P}$ content showed a quadratic response towards $\mathrm{Zn}$ foliar spray concentration (Figure $5 \mathrm{c}$ ). $\mathrm{Zn}$ applications at $0.09 \%$ induced shoot $\mathrm{P}$ content of $0.27 \%$. Other macro elements as $\mathrm{N}$ and Ca didn't show any significant difference between treatments and were in adequate levels (DATA not shown here).
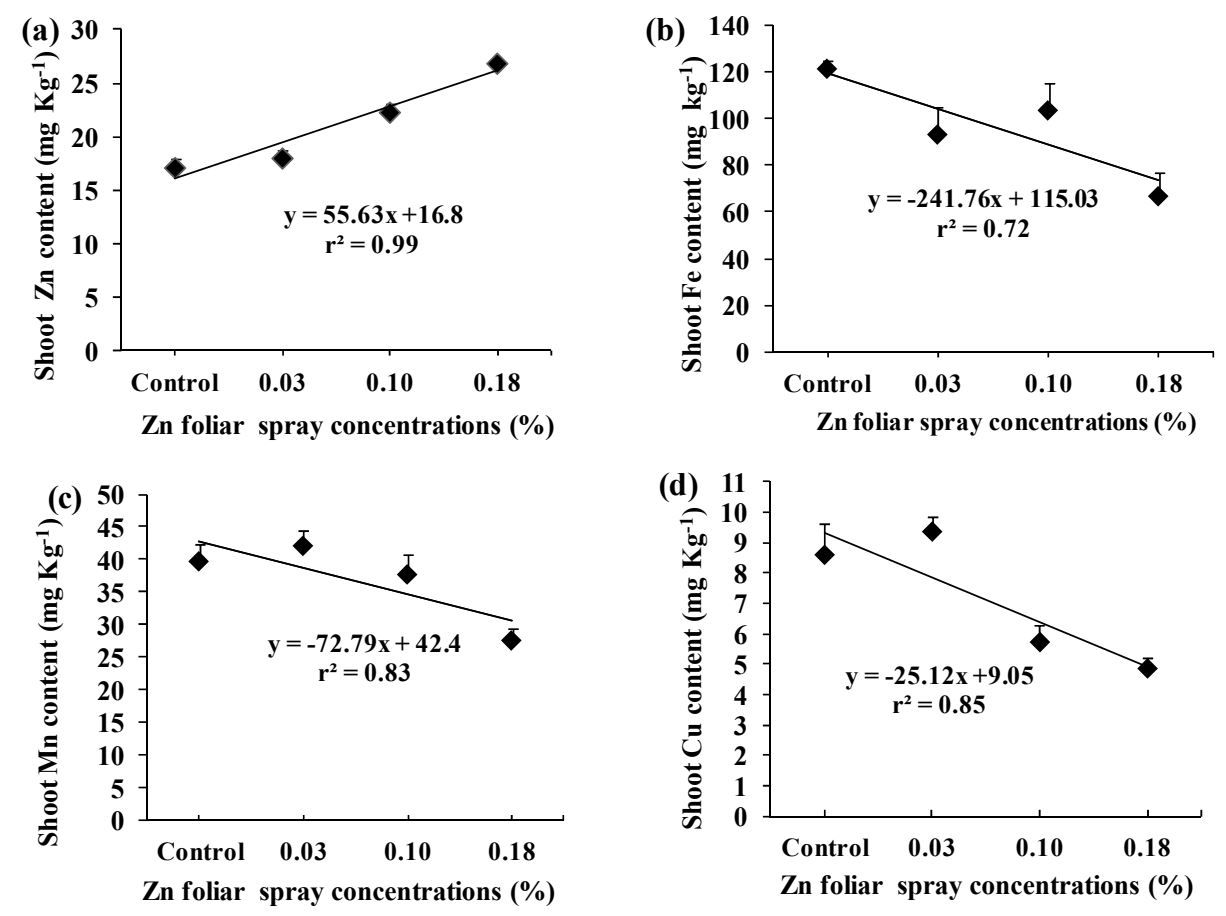

Figure 4. Effect of Zn foliar spray concentration on $\mathrm{Zn}(\mathrm{a}), \mathrm{Fe}(\mathrm{b}), \mathrm{Mn}$ (c) and $\mathrm{Cu}$ (d) contents of the shoot dry matter for corn silage at harvest. Vertical bars denote standard deviation 

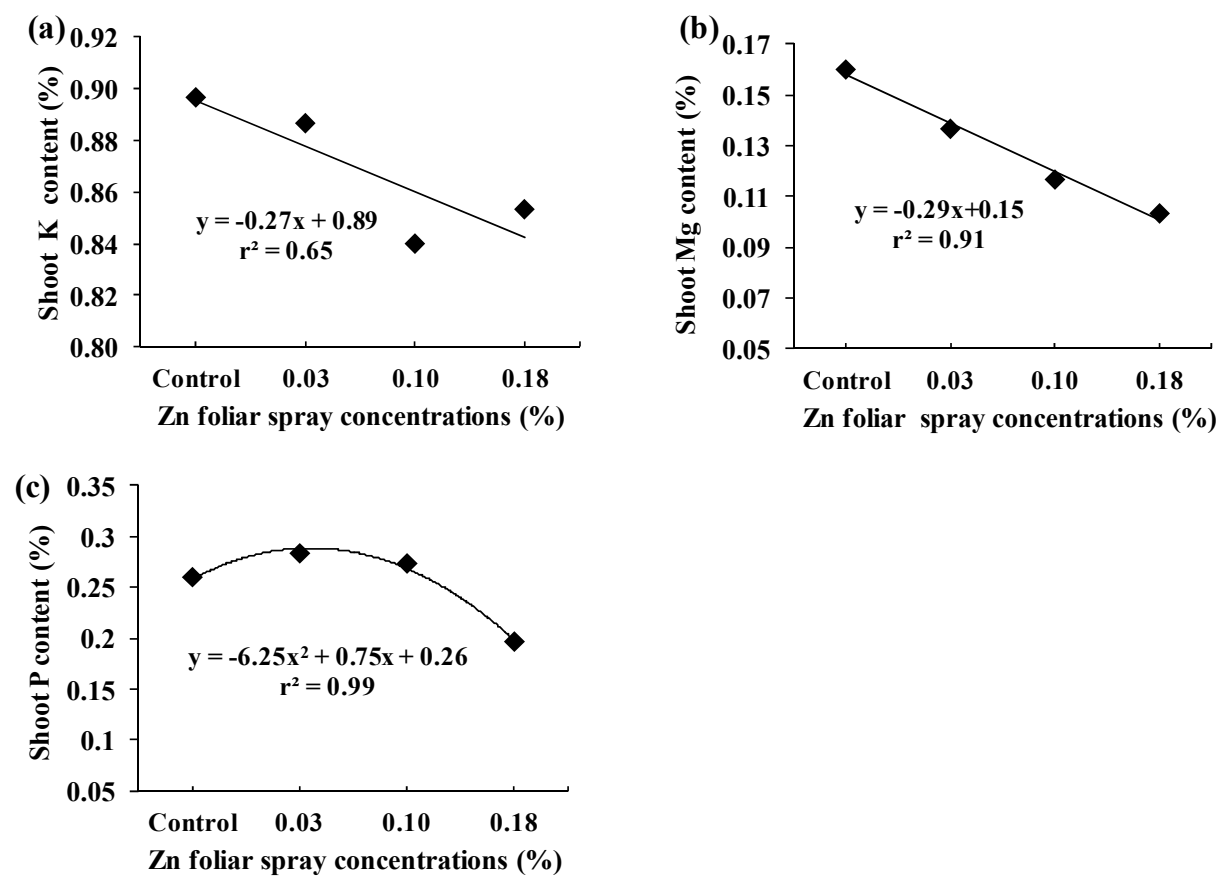

Figure 5. Effect of $\mathrm{Zn}$ foliar spray concentration on $\mathrm{K}(\mathrm{a}), \mathrm{Mg}(\mathrm{b})$, and $\mathrm{P}(\mathrm{c})$ contents of the shoot dry matter for corn silage at harvest. Vertical bars denote standard deviation

\section{Discussion}

Results from the present study have shown that Zn foliar spray prevented Zn deficiency stress in corn when it's applied at adequate level. Approximately $0.09 \%$ is the optimum $\mathrm{Zn}$ foliar spray concentration for corn silage production when grown in $\mathrm{Zn}$ deficient sandy soil. Furthermore, adverse effect on plant growth can happen with higher $\mathrm{Zn}$ foliar spray concentration.

\subsection{Visual Zn Deficiency Symptoms}

The appearance of $\mathrm{Zn}$ deficiency symptoms on corn was mainly attributable to a low soil born $\mathrm{Zn}$ content $(0.13$ $\mathrm{mg} \mathrm{kg} \mathrm{g}^{-1}$ ) which was below the critical level of $0.8 \mathrm{mg} \mathrm{kg}^{-1}$ required for corn production (Landsay \& Norvel, 1977). Their appearance at an earlier stage (5-6 leaf stage) was reported by many authors (Kuldeep \& Banerjee, 1986; Sharma, Chatterjee, \& Saharma, 1990; Wang \& Jin, 2007). As soon as we increased Zn foliar spray concentration, these symptoms became less severe. The same result was reported by Kaya and Higgs (2002) on tomato. Nevertheless, the slight recovery from Zn deficiency noticed in control plants at 8-9 leaf stage agreed with earlier result reported by Rungruang, Doyle, and Raymond (1978). On the other hand, the clear leaf injury noted at high $\mathrm{Zn}$ foliar spray concentration (up to $0.10 \%$ ) was noticed in rice with $\mathrm{Zn}$ foliar spray concentration up to $0.03 \%$ (Qiao et al., 2014) and in tomato at $0.015 \%$ of Zn (Kaya \& Higgs, 2002).

\subsection{Plant Growth, Silage Yield and Shoot Dry Matter Partitioning}

Synchronization of visual $\mathrm{Zn}$ deficiency symptoms and stem height shortening in control and low $\mathrm{Zn}$ foliar spray concentrations $(0.03 \%$ and $0.07 \%)$ supported the physiological mediating function of $\mathrm{Zn}$ in the metabolism of growth regulators as indole 3 acetic acid and gibberellic acid (Cakmak, Marshner, \& Bangerth, 1988; Balal et al., 1998). The leaf area was also enhanced by $\mathrm{Zn}$ foliar spray; a result which was reported by Chaab, Savaghebi, and Motesharezadeh (2011) on maize due to Zn soil supply. While no increase in stem diameter at harvest was noted, this result agreed with the finding of Rajabi et al. (2013) on safflower. In contrast, high Zn foliar spray concentration (up to $0.09 \%$ ) induced a clear inhibition of plant growth and yield decline, which agreed with the result of Kaya and Higgs (2002) on tomato. In this regard, a recent study by Qiao et al. (2014) explained that $\mathrm{Zn}$ foliar application at high concentration on rice, exceeding $0.03 \%$, induced a significant decrease in phosynthesis rate. They explained this decrease by the inhibition of chlorophyll synthesis and by inactivation of $\beta$-carbonic anhydrase enzyme which contains $\mathrm{Zn}$ and plays crucial role in photosynthesis.

Many authors reported the importance of $\mathrm{Zn}$ foliar applications at adequate levels to enhance yields of many 
crops such as corn (Potarzycki \& Grzebisz, 2009), wheat grain (Haslett, Reid, \& Rengel, 2001), tomato fruit (Kaya \& Higgs, 2002) and safflower (Rajabi et al., 2013). From this study, the highest silage yield was recorded with $\mathrm{Zn}$ foliar applications at $0.09 \%$ of $\mathrm{Zn}$, equivalent to $0.40 \%$ of $\mathrm{ZnSO}_{4} .7 \mathrm{H}_{2} \mathrm{O}$, applied at 5-6 and 9-10 leaf stages. Similarly, Lindsay (1972) reported in his review that $\mathrm{Zn}$ foliar applications at $0.5 \%$ of $\mathrm{ZnSO}_{4} \cdot 7 \mathrm{H}_{2} \mathrm{O}$, applied at 3 and at 5 leaf stages corrected Zn deficiency on corn. In contrast, Potarzycki and Grzebisz (2009) reported that optimal maize grain yield was recorded with high $\mathrm{Zn}$ foliar spray concentration ranging between $0.25 \%$ and $0.37 \%$ of $\mathrm{Zn}$. This latter was applied as oxysulfate at 5 leaf stage and was equivalent to $1.11-1.64 \%$ of $\mathrm{ZnSO}_{4} .7 \mathrm{H}_{2} \mathrm{O}$. Dry matter partitioning analysis showed that stem, leaves and ear biomass were all influenced by $\mathrm{Zn}$ foliar applications. The marked positive effect of $\mathrm{Zn}$ foliar spray on biomass can be explained through the role of $\mathrm{Zn}$ in increasing both the carbonic anhydrase enzyme activity (Qiao et al., 2014; Sasaki, Hirose, Watanabe, \& Ohsugi, 1998) and chlorophyll synthesis (Qiao et al., 2014; Cakmak \& Marshner, 1993), which improved photosynthesis rate (Qiao et al., 2014). As kernels presented about $50 \%$ of the total aerial dry matter (Figure 6), the silage yield response was especially linked to kernels weight. This latter was enhanced mainly through two components: thousand-kernel dry weight and pollination rate. The increase of thousand-kernel dry weight was reported by Potarzycki and Grzebisz (2009) on corn, and by Rajabi et al. (2013) on safflowers. It could be attributed mainly to photosynthesis activation mentioned above. Regarding pollination rate, its increase with adequate $\mathrm{Zn}$ foliar application can be related to male fertility enhancement found by Sharma et al. (1990).

\subsection{Mineral Shoot Content}

Control plants showed insufficient shoot $\mathrm{Zn}$ content at harvest $\left(15.8 \mathrm{mg} \mathrm{Kg}^{-1}\right)$ which was below the critical level required in corn $22 \mathrm{mg} \mathrm{kg}^{-1}$ (Singh et al., 2005). This content was linearly increased with raising Zn foliar spray concentration, the same result was reported by Cakmak et al. (2010) on wheat and by Kaya and Higgs (2002) on tomato. This linear positive relationship illustrates the luxurious consumption character of corn silage towards $\mathrm{Zn}$.

$\mathrm{Zn}$ foliar supplementations at $0.09 \%$, which induced the highest silage yield, provided an adequate shoot $\mathrm{Zn}$ content (21.8 $\left.\mathrm{mg} \mathrm{kg}^{-1}\right)$. This was approximately equal to the critical level cited above (22 mg kg$)$. Adequate $\mathrm{Zn}$ level in corn can both enhance silage nutritional quality and suppress or minimize $\mathrm{Zn}$ feed additives supply used in dairy cattle feeding. Even if we remarked negative relationships between shoot $\mathrm{Zn}$ content and $\mathrm{Mg}\left(\mathrm{r}^{2}=0.73\right)$, $\mathrm{K}\left(\mathrm{r}^{2}=0.59\right), \mathrm{Mn}\left(\mathrm{r}^{2}=0.63\right), \mathrm{Cu}\left(\mathrm{r}^{2}=0.68\right)$ and $\mathrm{Fe}\left(\mathrm{r}^{2}=0.59\right)$ at harvest, $\mathrm{Zn}$ foliar spray at $0.09 \%$ resulted in adequate plant content of $\mathrm{k}(0.8 \%)$ which was approximately equal to the critical level ranging between $0.7 \%$ and $0.9 \%$ (Arnon, 1975). Also, it induced adequate levels of Mn, Cu and Fe (Rashid \& Ryan, 2008). The plant $\mathrm{Mg}$ content $(0.12 \%)$ was lower than the adequate concentration of $0.20 \%$ requested for corn silage by Fox and Piekielek (1984). In the case of this study, no Mg deficiency symptoms were noticed. In this context, Arnon (1975) reported that $\mathrm{Mg}$ deficiency symptoms in corn appeared at $\mathrm{Mg}$ concentration below $0.06 \%$, and content around $0.12 \%$ and $0.24 \%$ induced optimal yields.

The negative interactions between $\mathrm{Zn}$ and other nutrients were in line with the finding of Kaya and Higgs (2002) who reported that $\mathrm{Zn}$ foliar applications on tomato induced antagonism between $\mathrm{Zn}$ and $\mathrm{K}, \mathrm{Mg}$ and Fe. The same relationship was found between $\mathrm{Zn}$ and $\mathrm{Cu}$ (Kumar et al., 2009) and between $\mathrm{Zn}$ and Fe (Ai-Qing et al., 2011) on wheat. This kind of interaction, which is presumably related to an inhibition of elements uptake due to $\mathrm{Zn}$ foliar applications, hasn't been well explained in the literature yet, and gives a reason for further investigation.

The shoot $\mathrm{P}$ content behaved differently from the other elements; it was enhanced with slight $\mathrm{Zn}$ concentration applications (below or equal to $0.06 \%$ ) and decreased with higher ones (up to $0.06 \%$ ). At an earlier study, Orabi, Mashadi, Abdllah, and Morsy (1981) found a positive relationship between P and Zn on corn. However, Zhu, Smith, and Smith (2001) reported that high soil P supply induced a low Zn content on wheat. Interaction between $\mathrm{P}$ and $\mathrm{Zn}$ is widely reported in the literature for different crops, but little is known about the specific mechanism involved either under $\mathrm{Zn}$ foliar spray or soil $\mathrm{Zn}$ supply. On the other hand, the optimal silage yield recorded at $0.09 \%$ had an adequate $\mathrm{P}$ content $(0.27 \%)$ which was around the required level (0.1-0.5\%) (Arnon, 1975). 


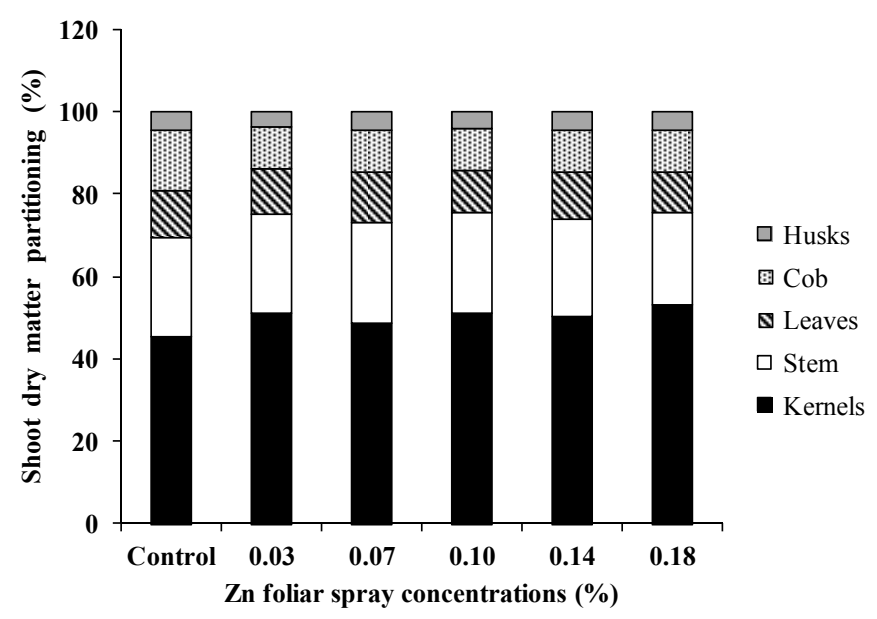

Figure 6. Effect of $\mathrm{Zn}$ foliar spray concentration on ratio of kernels, stem, leaves, cob and husks dry weights to total shoot dry weight

\section{Conclusion}

Results have indicated that $0.09 \%$ of $\mathrm{Zn}$, using as source $\mathrm{Zn}$ sulfate $\left(\mathrm{ZnSO}_{4} \cdot 7 \mathrm{H}_{2} \mathrm{O}\right)$, is the adequate concentration to spray at 5-6 and 8-9 leaf stages of corn silage in order to cure $\mathrm{Zn}$ deficiency. Such level of concentration proved to increase plant $\mathrm{Zn}$ content without any disruption in plant mineral composition, and to enhance plant growth, thereby increasing silage yield. However, caution must be taken with $\mathrm{Zn}$ foliar spray at concentration up to $0.10 \%$ which induced leaf injury, disrupted mineral plant composition and inhibited plant growth.

\section{Acknowledgements}

The authors are grateful to Mr. Loultiti M. M. and Mr. Coquant J. M. for their financial support. We wish to thank Mrs. Mouhatdi R., Mrs. Zehri B., Mr. Ziti S., Mr. Soulaimani A., Mr. Touhami D. and Mr. Daoudi M. for their valuable help during laboratory analysis. We also acknowledge Dr. Yacholti and Mr. El Gharradi Y. O. for language correction.

\section{References}

Ai-Qing, Z., Qiong-Li, B., Xiao-Hong, T., Xin-Chun, L., \& Gale, W. J. (2011). Combined effect of iron and zinc on micronutrient levels in wheat (Triticum aestivum L.). Journal of Environemental Biology, 32, 235-239. Retrieved from http://www.jeb.co.in/journal_issues/201103_mar11/paper_16.pdf

Alloway, J. B. (2008). Zinc in soils and crop nutrition (2nd ed.). International Zinc Association Communications. IZA Publications, Brussel. $\quad$ Retrieved from $\mathrm{http}: / /$ www.zinc.org/general/Zinc_in_Soils_and_Crop_Nutrition_ALLOWAY.pdf

Arnon, I. (1975). Mineral nutrition of maize. International Potash Institute, Bern. Retrieved from http://www.ipipotash.org/udocs/mineral_nutrition_of_maize.pdf

Balal, H., Norihiro, H., Yoshitaka, N., Masahito, S., \& Hiroshi, T. (1998). Zinc nutrition and levels of endogenous Indole-3-acetic acid in radish shoots. Journal of Plant Nutrition, 21, 1113-1128. http://dx.doi.org/ 10.1080/01904169809365470

Cakmak, I., Kalayci, M., Kaya, Y., Torun, A. A., Aydin, N., Wang, Y., ... Horst, W. J. (2010). Biofortification and localization of zinc in wheat grain. Journal of Agricultural and Food Chemistry, 58, 9092-9102. http://dx.doi.org/10.1021/jf101197h

Cakmak, I. (2008). Enrichment of cereal grains with zinc: Agronomic or genetic biofortification? Plant and Soil, 302, 1-17. http://dx.doi.org/10.1007/s11104-007-9466-3

Cakmak, I., \& Marshner, H. (1993). Effect of zinc nutritional status on activities of superoxide radical and hydrogen peroxide scavenging enzymes in bean leaves. Plant and Soil, 155-156, 1127-1130. http://dx.doi.org/ 10.1007/BF00025000

Cakmak, I., Marshner, H., \& Bangerth, F. (1988). Effect of zinc nutritional status on growth, protein metabolism and levels of indole 3 acetique acid and other phytohormones in bean (Phaseolus vulgaris). Journal of 
Experimental Botany, 40, 405-412. http://dx.doi.org/10.1093/jxb/40.3.405

Chaab, A., Savaghebi, Gh. R., \& Motesharezadeh, B. (2011). Differences in the zinc efficiency among and within maize cultivars in a calcareous soil. Asian Journal of Agricultural Sciences, 3, 26-31. Retrieved from http:/www.maxwellsci.com/print/ajas/v3-26-31.pdf

De Vasconcelos, A. C. F., Clístenes, W. A. N., \& Fernando, F. C. F. (2011). Distribution of zinc in maize plants as a function of soil and foliar Zn supply. International Research Journal of Agricultural Science, 1, 1-5. Retrieved from http://interesjournal.org/IRJAS/Pdf/2011/March/de\%20Vasconcelos\%20et\%20al.pdf

Fox, R. H., \& Piekielek, W. P. (1984). Soil magnesium level, corn (Zea mays L.) yield, and magnesium uptake. Communications in Soil Science and Plant Analysis, 15, 109-123. http://dx.doi.org/10.1080/00103628409367459

Gupta, U. C., Kening, W. U., \& Siyuan, L. (2008). Micronutrients in soils, crops and livestock. Earth Science Frontiers, 15, 110-125. http://dx.doi.org/10.1016/S1872-5791(09)60003-8

Hansch, R., \& Mendel, R. R. (2009). Physiological functions of mineral micronutrients (Cu, Zn, Mn, Fe, Ni, Mo, B, Cl). Current Opinion in Plant Biology, 12, 259-266. http://dx.doi.org/10.1016/j.pbi.2009.05.006

Haslett, B. S., Reid, R. J., \& Rengel, Z. (2001). Zinc mobility in wheat: Uptake and distribution of zinc applied to leaves or roots. Annals of Botany, 87, 379-386. http://dx.doi.org/10.1006/anbo.2000.1349

Kaya, C., \& Higgs, D. (2002). Response of tomao (Lycopersicon esculentum L.) cultivars to foliar application of zinc when grown in sand culture at low zinc. Scientia Horticulturae, 93, 53-64. http://dx.doi.org/10.1016/S0304-4238(01)00310-7

Knoche, M., Petracek, P. D., Bukovac, M. J., \& Shafer, W. E. (1994). Urea penetration of isolated tomato fruit cuticles. Journal of the American Society for Horticultural Science, 119, 761-764. Retrieved from http://journal. ashspublications.org/content/119/4/761.full.pdf

Kuldeep, S., \& Banerjee, N. K. (1986). Growth and zinc content of maize (Zea mays L.) as related to soil-applied zinc. Field Crops Research, 13, 55-61. http://dx.doi.org/10.1016/0378-4290(86)90007-9

Kumar, R., Mehrotra, N. K., Nautiyal, B. D., Kumar, P., \& Singh, P. K. (2009). Effect of copper on growth, yield and concentration of $\mathrm{Fe}, \mathrm{Mn}, \mathrm{Zn}$ and $\mathrm{Cu}$ in wheat plants (Triticum aestivum L.). Journal of Environemental Biology, 30, 485-488. Retrieved from http://www.jeb.co.in/journal_issues/200907_jul09/paper_03.pdf

Lindsay, W. L., \& Norvell, W. A. (1977). Development of a DTPA soil test for zinc, iron, manganese, and copper. Soil Science Society of America Journal, $421-428$. http://dx.doi.org/\%2010.2136/sssaj1978.03615995004200030009x

Lindsay, W. L. (1972). Zinc in soils and plant nutrition. Advances in Agronomy, 24, $147-186$. http://dx.doi.org/10.1016/S0065-2113(08)60635-5

Mokhtarpour, H., The, C. B. S., Saleh, G., Selamat, A. B., Asadi, M. E., \& Kamkar, B. (2010). Non destructive estimation of maize leaf area, fresh weight, and dry weight using leaf length and leaf width. Communications in Biometry and Crop Science, 5, 19-26. Retrieved from http://agrobiol.sggw.waw.pl/ cbcs/articles/CBCS_5_1_4.pdf

Mousavi, S. R., Galavi, M., \& Rezaei, M. (2013). Zinc (Zn) importance for crop production - A review-. International Journal of Agronomy and Plant Production, 4, 64-68. Retrieved from http://ijagcs.com/wp-content/uploads/2013/01/1881-18841.pdf

Orabi, A. A., Mashadi, H., Abdllah, A., \& Morsy, M. (1981). Effect of zinc and phosphorus on the grain yield of corn (Zea mays L.) grown on a calcareous soil. Plant and Soil, 63, 291-294. http://dx.doi.org/10.1007/BF02374607

Potarzycki, J., \& Grzebisz, W. (2009). Effect of zinc foliar application on grain yield of maize and its yielding components. Plant Soil Environment, 55, 519-527. Retrieved from http://www.agriculturejournals.cz/publicFiles/13721.pdf

Qiao, X., He, Y., Wang, Z., Li, X., Zhang, K., \& Zeng, H. (2014). Effect of foliar spray of zinc on chloroplast b-carbonic anhydrase expression and enzyme activity in rice (Oryza sativa L.) leaves. Acta Physiologia Plantarum, 36, 263-272. http://dx.doi.org/10.1007/s11738-013-1407-6

Rajabi, M., Fetri, M., Eghbal, G. M., Faraji, A. M. H., \& Asadian, G. (2013). Foliar application of Zn and Mn fertilizers on yield and yield components of safflower (Carthamus tinctorius L.) cultivars. International 
Journal of Agriculture and Crop Sciences, 5, 718-722. Retrieved from http://ijagcs.com/wp-content/uploads/2013/ 04/718-722.pdf

Rashid, A., \& Ryan, J. (2008). Micronutrient constraints to crop production in the Near East. Potential significance and management strategies. In V. B. Alloway (Ed.), Micronutrient Deficiencies in Global Crop Production (pp. 149-180). Springer Netherlands. http://dx.doi.org/10.1007/978-1-4020-6860-7_6

Rungruang, I., Doyle, P., \& Raymond, L. (1978). Utilization and redistribution of Zn during vegetative growth of corn. Agronomy Journal, 70, 243-246. http://dx.doi.org/10.2134/agronj1978.00021962007000020008x

Sasaki, H., Hirose, T., Watanabe, Y., \& Ohsugi, R. (1998). Carbonic anhydrase activity and $\mathrm{CO}_{2}$ transfer resistance in $\mathrm{Zn}$ deficient rice leaves. Plant Physiology, 118, 929-934. http://dx.doi.org/10.1104/pp.118.3.929

Sharma, P. N., Chatterjee, A. S. C., \& Saharma, C. P. (1990). Zinc deficiency and pollen fertility in maize (Zea mays). Plant and Soil, 124, 221-225. http://dx.doi.org/10.1007/BF00009263

Singh, B., Natesan, S. K. A., Singh, B. K., \& Usha, K. (2005). Improving zinc efficiency of cereals under zinc deficiency. Current Science, 88, 36-44. Retrieved from http:/www.iisc.ernet.in/currsci/jan102005/36.pdf

Takkar, P. N., \& Walker, C. D. (1993).The distribution and correction of zinc deficiency. In A. D. Robson (Ed.), Zinc in soil and plants (pp. 151-166). Kluwer Academic Publishers, Dordrecht, the Netherlands. http://dx.doi.org /10.1007 /978-94-011-0878-2_11

Van Biljon, J. J., Wright, C. A., Fouche, D. S., \& Botha, A. D. P. (2010). A new optimum value for zinc in the main maize producing sandy soils of South Africa. South African Journal of Plant and Soil, 27, $252-255$. http://dx.doi.org/10.1080/02571862.2010.10639994

Wang, H., \& Jin, Ji-Y. (2007). Effects of zinc deficiency and drought on plant growth and metabolism of reactive oxygen species in maize (Zea mays L.). Agricultural Sciences in China, 6, 988-995. http://dx.doi.org/10.1016/S1671-2927(07)60138-2

Wojcik, P. (2004). Uptake of mineral nutrients from foliar fertilization. Journal of Fruit and Ornamental Plant Research, 12, 201-218. Retrieved from http://www.insad.pl/files/journal_pdf/journal_2004spec/full2004-24spec.pdf

Zhu, Y. G., Smith, S. E., \& Smith, F. A. (2001). Zinc (Zn)-phosphorus (P) interactions in two cultivars of spring wheat (Triticum aestivum L.) differing in $\mathrm{P}$ uptake efficiency. Annals of Botany, 88, 941-945. http://dx.doi.org/ 10.1006/ anbo.2001.1522

\section{Copyrights}

Copyright for this article is retained by the author(s), with first publication rights granted to the journal.

This is an open-access article distributed under the terms and conditions of the Creative Commons Attribution license (http://creativecommons.org/licenses/by/3.0/). 